\title{
2. 温暖化防止の政策と法
}

Policies and laws for the prevention of global warming

椎名㯖太郎*

Shintaro Shiina*

1 温暖化防止の国際的合意とこれに伴う義務

（1）国際条約とその憲法上の位置づけ（憲法 98 条 2 項は「日本国が締結した条約」の「誠実に遵守寸 ることを必要とする」と定める。

気候変動枠組み条約とその義務の具体化文書としての京都議定書（1997 年、日本は 2002 年批准）

（2）＼cjkstart京都議定書発効の条件は、以下の両方の条件を満たす必要があった。

(1) 55 力国以上の国が締結

(2) 締結した附属書 I 国（先進国、積極的に参画した諸国）の合計の二酸化炭素の 1990 年の排出量が、 全附属書 I 国の合計の排出量の $55 \%$ 以上

後者の条件について、世界最大の二酸化炭素発生国であるアメリカ合衆国が国内事情により締結を見送っ ているため、クリアできるかどうか際どい状況であった。

発展途上国の自発的参加が見送られ、アメリカ合衆国が受け入れを拒否、ロシア連邦も受け入れの判断を 見送っていたため、2004 年ごろまでは議定書の発効の見通しが不透明であった。しかし、ロシア連邦が批准 したことにより 2005 年 2 月 16 日に発効した。

（3）京都議定書の求める義務とその履行メカニズム

A 先進締約国全体で、2008 年からの 5 年間の平均で、温室効果ガスを炭素換算で 1990 年レベルより少な くとも 5 \%削減すること。対象ガスには二酸化炭素、メタン、亜酸化窒素に加え、HFC、PFC、及び 6 フッ 化硫黄が含まれる。 HFC、PFC、及び 6 フッ化硫黄については、1995 年を基準年として選ぶことができ るとされる。

B 排出量は国ごとに違い、アイスランドの $10 \%$ 増、オーストラリアの $8 \%$ 増から、ロシア、ウクライナ、 ニュージーランドの $0 \%$ 、クロアチアの $5 \%$ 減、カナダ・日本が $6 \%$ 減、アメリカ $7 \%$ 減 HFC、PFC、及び 6 フッ化硫黄、EU 諸国の $8 \%$ 減まで幅がある。

C 吸収源については、1990 年以降の新規植林、再植林及び森林消失による炭酸ガスの蓄積の変化量を算定 することが認められている。

D＼cjkstart京都メカニズムと総称される義務履行及び排出枠拡大のための仕組みが認められている。

* 山梨学院大学法科大学院

Law School, Yamanashi Gakuin University 


\section{京都メカニズムの概要}

\section{[1]排出量取引}

先進国間で排出枠を移転。

先進国全体の総排出枠は変化しない。

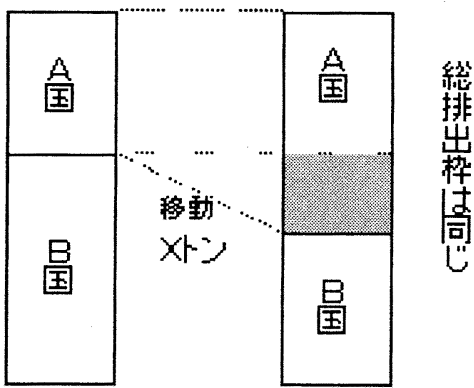

\section{[2]共同実施}

・先進国間で温室効果ガス削減事業を実施、その結果生じた削減単位をホス卜国から投資国に移転。

・先進国全体の総排出枠に影響を与えない。

ホ자国の排出挅の恋化

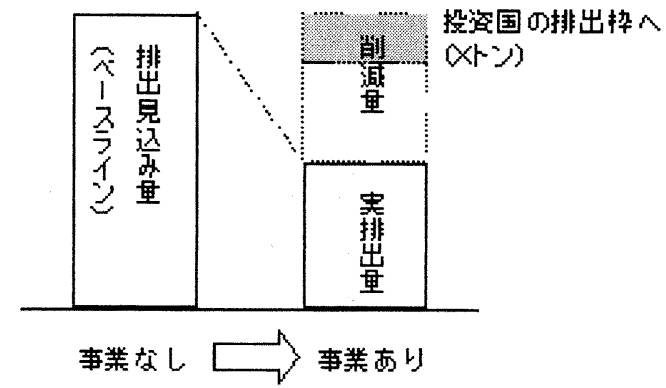

投诰国・本不国間の排出伜 $\sigma$ 移転

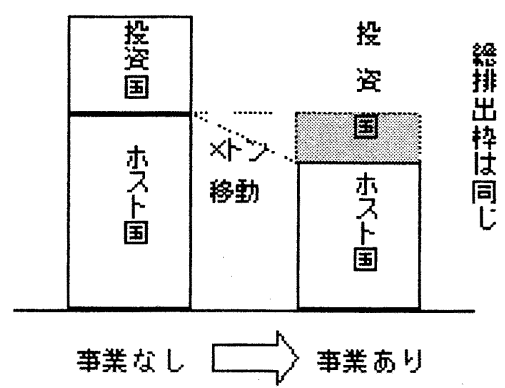

\section{[3]クリーン開発メカニズム}

·先進国が途上国（非附属書 I 国）において実施された温室効果ガスの排出削減事業から生じた削減分 を獲得することを認める制度。総排出枠は増加。

先進国は削減分を目標達成に活用、途上国にとっても、投資と技術移転の機会。

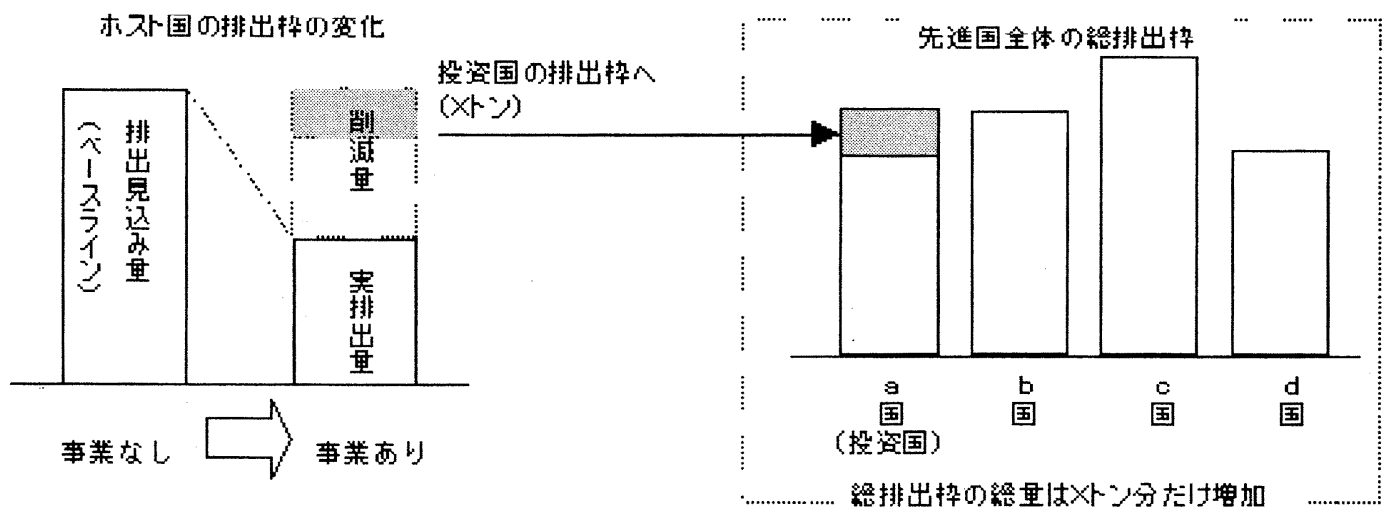

2 京都議定書の履行の現段階

（1） EU 諸国の対応 1

EU は京都議定書採択時の 15 力国（EU15）全体で 8\%減という義務を負っているが、EU そのものが主 権国家ではないために、その政策決定と履行には EU 機関だけでなく、構成各国政府及び各国の利害関係者 が関与する複雑な要素がある。構成国は EU に主権の一部を委譲し、EU 全体で政策を決定するほうが政策 
目的を達成できる場合には、EUが政策決定を行う。

EU15 の中でも削減目標は大きく異なっている。ルクセンブルグが $28 \%$ 減、デンマークとドイツが $21 \%$ 減、英国が $12 \cdot 5 \%$ 減と大きな負担を担っているのに対して、フランスは $0 \%$ 、ポルトガルは $27 \%$ 増、ギリ シャは $25 \%$ 増などとなっている。

EU 全体としては、1990 年から 2001 年までの間に、温室効果ガスを $2 \%$ 削減した。しかし、このほとん どはドイツとイギリスの貢献であり、この両国の削減分の半分以上は旧東ドイツ地域でのエネルギー効率向 上とイギリスの燃料転換 2 にるものである。従って、ここでの目標達成も楽観できないとされる。

そこで、EUではつぎのような点が重要であるとされる。

(1) 排出枠取引による産業・エネルギー部門の排出抑制

(2) 運輸・民生部門の対策強化

(3) 京都メカニズムの利用

(4) 新規加盟国の動向

(2) アメリカの対応 3

米国は最大の温室効果ガス排出国（1998 年データで世界全体の $24.8 \%$ ）でありながら、2001 年に京都議 定書から離脱した。しかし、アメリカが温暖化対策に全く背を向けているわけではない。

A 連邦レベルの対策

連邦行政府では、経済成長を維持しながら対策を進めるという観点から、温室効果ガス排出総量ではなく 国内総生産（GDP）原単位当たりの削減をめざし、2012 年までに 2002 年レベルより $18 \%$ 削減することを 目標としている。この原単位アプローチでは、年 $3 \%$ の経済成長率下では、2012 年に米国の排出量は $30 \%$ 増加するとされる。しかし、長期的には技術革新によって GDP 原単位当たりの削減幅を大きくすることが 可能であり、その削減幅が経済成長率を上回ることで、絶対量としての排出量安定化が達成できるとする。 具体的には水素エネルギーや炭素隔離・貯蔵の分野での革新的技術開発が進められている。

連邦議会では、2003 年に上院に Climate Stewardship Act（気候管理人法）が提案されたが、55 対 43 で 否決された。この法案は大規模温室効果ガス排出企業に 2010 年までにその排出量を 2000 年レベルに削減を 義務付けるほか、キャップ・アンド・トレード型排出量取引制度導入を目指していた。その後、下院でも提 案され、法案成立をめざす活動は続いているが、原子力産業がこれをサポートしているといら情報もある。

$\mathrm{B}$ 各州政府レベルの取組み

連邦レベルの取組みはかなり消極的であるが、この問題では、ブッシュ政権と国民の意識には大きなギヤ ップがあるとされ、州政府や民間企業の取組みに注目する必要がある。

地域が広大なアメリカでは、各州の位置により、温暖化対策への取組みに差異があり、一部の州はかなり 真剣にこの問題に取り組んでいる。また、ここには温暖化対策ビジネス機会という観点も無視できない。テ キサス州の 1998 年の排出量は世界全体の $2.8 \%$ であり、これは英国、カナダの $2.5 \%$ 上回る。具体的取り 組みの例としては、発電量中の再生可能エネルギ一の達成基準を定めている州（カリフォルニア州では 2020 年までに $33 \%$ 、テキサス州では 2015 年までに $5880 \mathrm{MW} 、$ ニーヨーク州では 2013 年までに $25 \%$ など)、 温室効果ガスの排出削減目標を定めている州（カリフォルニア州では 2010 年に 2000 年レベル、2020 年に は 1990 年レベル、2050 年には 1990 年レベルの $80 \%$ 減、マサチューセッツ州では 2010 年に 1990 年レベ ル、2020 年に 1990 年の $10 \%$ 減、長期的には 1990 年の 75 ～ $85 \%$ 減など）などがある4。

C 民間企業レベル

温暖化対策に反対してきた産業界でも、長期的な観点から温室効果ガス削減の取組みが避けられないと考 える会社が出始めている。デュポンは温室効果ガス排出削減目標を 2010 年までに 1990 年比で $65 \%$ と、 すでに達成している。大手ハイテク機器メーカーUnited Technologies は売上高当たりのエネルギー消費量 を 2007 年までに 1997 年比で $27 \%$ 削減する目標を揭げ、これを 2003 年までにクリアしている。こうした 
民間企業の行動の背景には気候変動そのものが企業活動への悪影響をもたらすことに加えて、政府が削減量 を立法化した場合の経営リスクの認識がある。これらに関する情報公開を求める株主代表訴訟も起きている。

(3) 途上国問題の存在 5

途上国が当面削減義務を負わないことは、COP 1 (ベルリン) での合意。これは第一段階の国際合意とし て合理性をもっている。しかし、現在検討に入っているポスト京都議定書段階では、途上国という一括のく くりではなく、各国の実情に応じた責任が問われるはず。これについては、公平性の原則とその優先順位が 提唱されている。最も優先順位が高いのが電気を使う生活を享受する権利のような「開発の権利」である。 途上国の住民に一生電気を使うなとはいえない。第2 は支払い能力のあるひとが、より多く負担するという 「支払い能力」の原則。第 3 は「加害者責任」。一人当たりの排出量と責任や義務の大きさは比例すべきこ とになる。一番優先順位が低いのは「既得権」である。

こうした差異化をべースに国際的合意が成立するには、いくつかの課題がありうる。米国が数值目標をも たないのに、途上国だけが数值目標をもつのは政治的敗北（一方的妥協）だとする受け止め方がありうるこ と、一人当たり排出量で現在の先進国レベルに達しないうちに排出削減を始めなければならないことなど。

3 日本における温暖化防止政策と法制

（1）国家による社会介入の歴史的展開

例えば、フランス行政学では、経済的自由主義段階と介入主義（interventionnisme）段階を区別し、前者 では国家の機能は主として夜警であるという。この段階の法的手段として典型的なのは、許可制（ある種の 活動を一般的に禁止しておいて、国民・事業者の個別の条件によりこの禁止を解除する規制手法) である。 これに対して、国家が運輸やエネルギー供給などの経済活動の基盤整備を行うようになり、やがて経済活動 に積極的に介入する段階では、政策実現に法規制、税制、補助金や低利融資などの経済的手法、情報提供手 法、計画などさまざまな手段が組み合わされるようになり、法的にもより社会形成的な手段が用いられるよ うになる。温暖化対策は国や自治体が経済活動にかなりの介入をすると同時に、排出枠取引のように市場入 カニズムをも活用するという、極めて複雑な政策にならざるをえない。

（2）環境政策における各種の手法

大塚直教授は、環境政策における手法を(1)総合手法、(2)規制手法、(3)誘導手法・合意手法、(4)事後措置に 分けて解説している。。

(1)総合手法とは、環境基本計画や公害防止計画のようなものをいう。これらは予防的・長期的視点から環 境配慮をする上で役立つ。

(2)規制手法とは、法的規制を中心に問題に対処するもので、今日においても環境保護にとって重要な役割 を果たしている。

(3)誘導的手法・合意手法は広範囲な経済活動の方向付けなどを要する問題に対処する手段である。誘導的 手法には市場を使う手法と情報を使う手法がある。市場を使う手法の典型は経済的手法であり、補助金制度、 賦課金制度、排出枠取引、グリーン購入などがこれに含まれる。情報を使う手法としては、環境に関する自 己情報公開制度（環境監査、ISO 環境マネジメント）、PRTR 法（環境污染物質排出・移動登録法）などが 挙げられる。合意手法の典型は行政指導や公害防止協定や緑化協定などの協定手法である。

(4)事後措置としては、(1)〜3)の事前的措置ではなく、刑事罰、行政罰、損害賠償、原状回復など、主とし て裁判を通じてなされるのが特徵である。

（3）温暖化防止政策とそれを実現する政策手段

地球温暖化対策推進法（1998 年制定）は、その目的規定で「地球温暖化が地球全体の環境に深刻な影響を 及ぼすものであり、気候系に対して危険な人為的干渉を及ぼすこととならない水準において大気中の温室効 果ガスの濃度を安定化させ地球温暖化を防止することが人類共通の課題であり、すべての者が自主的かつ積 
極的にこの課題に取り組むことが重要であることにかんがみ、地球温暖化対策に関し、京都議定書目標達成 計画を策定するとともに、社会経済活動その他の活動による温室効果ガスの排出の抑制等を促進するための 措置を講ずること等により、地球温暖化対策の推進を図り、もって現在及び将来の国民の健康で文化的な生 活の確保に寄与するとともに人類の福祉に貢献すること」を目的として掲げている。ここでは「目標達成計 画の策定」と「温室効果ガスの排出抑制等の促進」が目的とされている。この目的はかなり複雑かつ困難性 を伴うもので、単にある種の活動を規制するといった個別措置で実現されるものではない。温暖化対策では、 複数の政策を組み合わせることを「ポリシー・ミックス」と呼んでいる。

ポリシー・ミックスとは、ある目標を達成するために複数の政策を組み合わせて使うことである。2005 年 4 月 28 日に策定された京都議定書目標達成計画では「経済的手法」・環境税」・「国内排出量取引制度」 を組み合わせている。環境税とは、ある活動に対して税金を課して、その活動を抑制する意味を持ち、また その税収は二酸化炭素を減らすための政策を行なうための財源となる。これについては、項を改めて若干の 説明を行う。国内排出量取引制度は、企業が割り当てられた二酸化炭素削減目標を超える削減量を達成した ときに、超えた分が換金される仕組みを作ることで、さらなる削減を促す政策である。目標達成計画ではこ の3者を組み合わせて二酸化炭素排出量の削減を達成しようとしている ${ }^{7}$ 。

ここで問題となるのが、なぜ組み合わせるのかである。京都議定書目標達成計画の組み合わされる 3 つの 政策は、意味的に 2 つに分類できる。政策の適用される企業等にとって「嫌な状況を作り出す政策」と「好 ましい状況を作り出寸政策」である。「経済的手法」は、二酸化炭素削減のためにふさわしい行動に対し補助 金を出すことで、企業等にとって他の行動をとるよりも環境省の意に沿う方が「好ましい」状況を作り出す。

「環境税」は、二酸化炭素削減にふさわしくない行動に税を課して強制的にコストアップさせることで、企 業がその行動を行うのに「嫌な」状況をつくりだす。「国内排出権取引制度」は両面性をもつ。二酸化炭素削 減に積極的な企業にとっては、目標を超えた努力を現金化することが出来、「好ましい」状況をつくりだす。 積極的でない企業にとっては、目標を達成できなかった分を、達成できた企業から相応の值段で買い取らね ばならなくなり、コスト的に「嫌な」状況を作り出すことになる。

つまり政策ミックスとは、二酸化炭素削減という政策にとってふさわしい行動を行うように誘導し、ふさ わしくない行動をしないように誘導するための、アメとムチを組み合わせた政策と言うことができる。

（4）日本の温暖化防止の法制

A 地球温暖化対策推進法 (1998 年)

前述の目的規定のほか、国、地方公共団体、事業者、国民の各々の責務、政府の京都議 定書目標達成計画策定義務、内閣に地球温暖化対策推進本部設置すること等が規定されて おり、具体的施策としては、政令で定める基淮以上の温室効果ガス排出事業者（国又は地 方公共団体の事務事業を含む）に、毎年、一定期間に排出した温室効果ガス算定排出量の 報告を義務付けていることが挙げられる程度。この報告義務には 20 万円以下の罰金という 罰則がついている。

B 新エネルギー利用促進特別措置法（1997 年 2005 年改正）

この法律は、内内外の経済的社会的環境に応じたエネルギ一の安定的かつ適切な供給の確保に資するため、 新エネルギ一利用等についての国民の努力を促すとともに、新エネルギ一利用等を円滑に進めるために必要 な措置を講ずることとし、もって国民経済の健全な発展と国民生活の安定に寄与すること」を目的としてい る。中身は簡単で、経済産業大臣に、新エネルギー利用促進の基本方針及びエネルギー使用者に対する新エ ネルギ一利用指針を定めて公表することを求めており、具体的措置としては、認定事業者制度（事業活動に おいて新エネルギー利用等を行おうとする者は、当該新エネルギ一利用等に関する計画を作成し、これを主 務大臣に提出して、その利用計画が適当である旨の認定を受けることができる）の創設がある。これはこの 事業への補助制度と結びついている。 


\section{C 電気事業者新エネルギー利用促進法（2002 年）}

この法律は、「内外の経済的社会的環境に応じたエネルギーの安定的かつ適切な供給の確保に資するため、 電気事業者による新エネルギ一等の利用に関する必要な措置を講ずることとし、もって環境の保全に寄与し、 及び国民経済の健全な発展に資すること」を目的として、電気事業者に風力、太陽光、地熱、水力、バイオ マスなどの新エネルギ一利用を促進させることを狙いとしている。具体的措置としては、電気事業者に対し て新エネルギーに関する基準利用量の届出を求め、この基準に達しない場合に経済産業大臣は勧告及び命令 をすることが出来るとされる。この命令に従わなかった場合の罰則は 100 万円以下の罰金となっている。

D 省エネ法 (1979 年、その後 1998 年、2002 年、2005 年に大きな改正がされた。

この法律は、正式名称を「エネルギーの使用の合理化に関する法律」といい、上記の法律とは違って、明 確な規制手法を用いている。この法律は昨年大きな改正が行われ、本年 4 月から施行された。

この法律はこの法律は、「内外におけるエネルギーをめぐる経済的社会的環境に応じた燃料資源の有効な 利用の確保に資するため、工場、輸送、建築物及び機械器具についてのエネルギーの使用の合理化に関する 所要の措置その他エネルギーの使用の合理化を総合的に進めるために必要な措置等を講ずることとし、もつ て国民経済の健全な発展に寄与すること」を目的としている。

\section{（1) 工場・事業場に係る措置}

これまで熱管理指定工場・事業所と電気管理指定工場・事業所に区別されていたが、今次改正により、工 場・事業所等で使われる熱と電気を合算して原油に換算し、その年間 $3000 \mathrm{kl}$ であるものを第 1 種エネルギ 一管理指定工場、 $1500 \mathrm{kl}$ 以上のものを第 2 種エネルギ一管理指定工場とする。経済産業省の外郭団体省工ネ ルギーセンターの解説では、対象工場・事業所はこれまでの 1 万から 1 万 3000 に拡大される。それぞれの 工場・事業場を設置している者を第 1 種特定事業者、第 2 種特定事業者と呼ぶ。

主務大臣は、第 1 種エネルギ一管理指定工場におけるエネルギーの使用の合理化の状況が経済産業大臣が 定める基準に照らして著しく不十分なときは、それを設置している第 1 種特定事業者に対し、その判断の根 拠を示して、エネルギーの使用の合理化に関する計画（以下「合理化計画」という。）を作成し、これを提 出すべき旨の指示をすることができる。また、提出された合理化計画がエネルギーの使用の合理化の適確な 実施を図る上で適切でないと認めるときは、合理化計画を変更すべき旨の指示をすることができる。

主務大臣は、第 1 種特定事業者が合理化計画を実施していないと認めるときは、当該第一種特定事業者に 対し、合理化計画を適切に実施すべき旨の指示（てれは行政指導と考えられる）をすることができる。この 指示に従わなかつたときは、主務大臣はその旨を公表することができる。さらに、指示を受けた第 1 種特定 事業者が、正当な理由がなくてその指示に係る措置をとらなかったときは、関係審議会の意見を聴いて、当 該第 1 種特定事業者に対し、その指示に係る措置をとるべきことを命ずることができる。この命令に従わな い場合には、百万円以下の罰金という罰則がある。第 2 種特定事業者の場合には、勧告までの権限が定めら れている。いずれの工場・事業場についても、必要な場合には設置者に報告を求め、実地の立ち入り検査を する権限が規定されている。ちなみに、会場校である学校法人山梨学院も第 2 種特定事業者に指定されてい る。

輸送に関する省エネ措置も規定されている。この分野では、荷物の輸送を自ら行っている者及び輸送を委 託している者で、荷重（トン）×輸送キロの総計が年間 3000 キロトン以上に及ぶ者を「特定荷主」と呼び、 これについて、第 1 種特定事業者に対するのと同じ規制がなされる。また、貨物・旅客輸送業者についても、 一定基準以上である者を「特定輸送事業者」に指定し、これについて第 1 種特定事業者と同様の規制措置が 規定されている。このほか、一定規模以上の住宅や非住宅建築物について、外壁・空等の断熱化、空調設備 の効率的な利用などに向けた措置、エネルギ一消費の大きい特定機器（自動車、エアコン、電気冷蔵庫など 18 機器）につき、効率化の基準が示され、これに向けて改善努力が求められている。ここでは、トップラン ナ一方式という手法が用いられている。これは、効率化の基準となる事項について、「判断の基準となる心゙ 
き事項は、当該特定機器のうち前条に規定する性能が最も優れているものの当該性能、当該特定機器に関す る技術開発の将来の見通しその他の事情を勘案して定めるものとする」と定めるもので、各業界の省エネ面 の最先端機種が改善の目標にされるものである。これについても、勧告及び命令の権限が定められている。 特定機器については、その省エネ性能を表示する制度も定められており、メーカーは消費電力量を本体や力 タログで表示する義務が課せられた。この秋から店頭の商品について省エネ详成努力率を 5 段階評価の星の 数で示す統一ラベルで表示することになった。ただし、小売店については、ラベル表示義務はない。 $\mathrm{E}$ その他（循環型社会形成推進基本法、資源有効利用促進法、各種リサイクル法など）

（5）環境税について

環境税が二酸化炭素を削減する上で有効な手段であることはいうまでもない。しかし、日本では業界団体 とこれと密接な関係を有する経済産業省が導入に反対の姿勢を崩しておらず、環境省の姿勢がかなり慎重な こともあって、実現へのめどはたたない。2004 年段階で環境省が示した具体案は、企業や家庭が排出する二 酸化炭素の量に忘じて課税するもので、税額は炭素換算で 1 トンあたり 2400 円、平年ベースで 4900 億円の 税収を見込み、これを一般財源化して温暖化対策や企業の社会保険料軽減などに使うといったものだった。 しかし、2005 年秋段階の案では、経済界の反対に気を使って、税収総額を 3700 億円程度におさえ、全額を 温暖化詨策費にあてることにしている。しかし、これは、インセンティヴにそしく、温暖化防止一の効果が 見込めるかどうか疑問視されている。

問題は政府が環境税を財政赤字対策の一環と考えていることである。ヨーロッパ諸国のうち環境税（多く は炭素税）を導入したところでは、この税収を既存の燃料税の減税・廃止、社会保険料・法人税・所得税の 軽減に使い、歳入全体としては増やさない税収中立型になっている。これは、二酸化炭素削減努力が企業活 動や経済の活性化につながり、努力した者が報われるシステムとなっている。実際の制度設計では、負担が 大きいエネルギー集約型産業への軽減措置や他のメカニズムとのポリシーミックスが重要である。日本の場 合には道路特定財源の見直しが当然必要となる8。

（6）国の対策と地方自治体の対策

A 温暖化対策における国と自治体

地球温暖化対策推進法では、地方自治体にも責務が定められている。法 4 条では、「地方公共団体は、そ の区域の自然的社会的条件に応じた温室効果ガスの排出の抑制等のための施策を推進するものとする」(1 項）とされ、また、地方公共団体は、自らの事業活動に関し温室効果ガスの排出の抑制等のための措置を講 ずるとともに、その区域の事業者又は住民が温室効果ガスの排出の抑制等に関して行う活動の促進を図るた め、前項に規定する施策等に関する情報の提供その他の措置を講ずるように努めるものとする」とされてい る。

2000 年から施行された地方分権改革法では、国が地方自治体を下部機関として扱ってきた機関委任事務制 度が廃止され、法定受託事務という特殊な範疇の事務を除けば自治体は各自の事務をかなり自由に展開でき ることとなった。地球温暖化対策推進法に基づく自治体の施策も自治事務であり、各々の自主性が発揮でき る面が少なくない。

日本列島は南北に長く、かなりの期間雪に覆われる雪国から、亜熱帯に属する沖縄県先島地域まで多様性 に富んでいる。当然、エネルギー対策もその区域の自然的社会的条件に応じたものでなければならない。地 球温暖化対策推進法では、各自治体に、「京都議定書目標達成計画に即して、当該都道府県及び市町村の事務 及び事業に関し、温室効果ガスの排出の抑制等のための措置に関する計画（実行計画）を策定することを求 め (21 条)、都道府県には NPO 法人である都道府県地球温暖化防止活動センターを置くように求めている

(24 条)。また、都道府県知事は地球温暖化防止対策に関する知識の普及と推進活動に熱意をもつ者を地球 温暖化防止活動推進員として委嘱することができる (23 条)。これらは、自治体にとっては法定自治事務と いうことになる。とくに、この都道府県センターがどのような活動をするかは対策の充実にとって大きな意 
味をもつ。

B 自治体の対策がカギ?

しかし、これ以外に各自治体がどのように創意をこらした対策を打ち出すかが温暖化対策の実効性という 観点から注目される。ここでは自治体の取り組みの温度差が感じられる。

全国で注目されたのは、長野県が 2003 年 4 月に明らかにした「地球温暖化県民計画」である。これは、 コンビニや郊外店の深夜営業や清涼飲料自販機の規制を打ち出したもので、業界からは営業妨害という声も あがったが、今年 3 月 30 日に公布され、 1 年以内に施行される予定の「長野県地球温暖化対策条例」では、 次のような形でこれを法制化した。

温室効果ガスの排出が相当程度多い事業者、終日営業の小売業者、飲料の自販機の設置・管理をする事業 者に対して、温室効果ガスの排出抑制計画の策定を義務づけている。この計画が提出されたときは、知事は これをインターネットなどで公表する。そして、これら事業者は計画の達成状況等を知事に報告することを 求められている (条例 12 条)。そして、知事は終日営業の小売業者、飲料の自販機の設置・管理をする事業 者に営業時間・稼働時間の短縮が温室効果ガス排出抑制に寄与することについて理解を求めると共に、小売 業者等との協定方式で排出抑制促進を図るとしている (13 条)。13 条は直接的規制手法を避けて、協定とい う合意形成手法での解決を優先したものといえる。

このほか、この長野県条例は、自動車利用について、マイカーから公共交通機関への利用転換、アイドリ ング・ストップ、温室効果ガス排出量の少ない車種の選定などを努力義務として定め、また、電気機器の小 売店において、知事が定める「省エネラベル」の掲出を義務づけるなど、意欲的な政策を条例化している。

隣県である山梨県も 2004 年 2 月に「地球温暖化対策推進計画」を明らかにしたが、この計画とリンクし た政策はあまり明確ではない。2005 年 10 月に施行された山梨県生活環境保全条例は、廃棄物の発生抑制と あわせてアイドリング・ストップと光害防止を打ち出しているが、長野県条例に比べると見劣りすることは 否めない。

（7）温暖化対策における市民・NPO の参加

温暖化防止対策推進に市民の参加が不可欠であることはいうまでもない。平田仁子氏は温暖化対策強化に おける市民参加の意義について、(1)取り組みを監視し評価するうえで、市民・NPO・専門家による監視と客 観的評価のしくみ、(2)温暖化防止への幅広い主体的な行動を促すしくみ、(3)適確な情報提供で賢い選択を促 すしくみ、という 3 方面から市民参加の重要性を指摘している9。この点についてはこれ以上の論述は不要 であると考える。

都道府県には NPO 法人である都道府県地球温暖化防止活動センターを置くことが、地球温暖化対策推進 法で定められ、実際にその指定がされているが、このセンターの活動が実際にどのようなものであるかにつ いては、詳しい情報を持っていない。

4 ポスト京都議定書の段階を前に

(1) 京都議定書と次のステップ

京都議定書は 2008 年から 5 年間を第 1 約束期間としており、その後の削減約束は今後の締約国会議に委 ねられている。この第 11 回気候変動枠組み条約兼第 1 回京都議定書締約国会議 (COP11・COPMOP1）が 2005 年 11 月 28 日から 12 月 9 日までカナダ・モントリオールで開催された。ようやく動き出した京都議定 書合意も、その目標達成が出来なかった場合の措置や合意に参加していないアメリカや途上国をどうするか など、困難な課題を残していたこことから、この会議の成果が注目された。

この会議では、(1)京都議定書の実施と既存の各制度の改善、(2)2013 年以降の取組みのあり方、(3)京都議定 書の削減目標を達成できなかった国への措置、が課題であった10。

(2) $\mathrm{COP} 11 \cdot \mathrm{COPMOP} 1$ の成果 11 
結論的にいうと、この会議は 12 月 10 日という最終日にようやく次期枠組みについて、次の 3 つの合意に 達して終った。これは決して容易なプロセスではなかったとされる。このうち、(1)と(2)は COPMOP1 の合 意であり、(3は COP11 での合意である。

(1) 次の約束期間の先進国の削減目標の改正

これについては、特別作業部会を設置し、2006 年 5 月の補助機関会合で第 1 回会合を開催。以後、毎年 の COPMOP で検討状況を報告。作業は、第 1 約束期間と第 2 約束期間との間に空白を生じないタイミング で終える。

(2) 議定書の見直し

COPMOP 2 で行う予定となっている議定書の見直しの準備を始める。この合意による議定書の見直しは、 条約の約束の達成状況や妥当性の検討と連動して行われるため、今後の途上国を含む取組みの議論につなが ると考えられる。また、世界全体での排出削減を進める糸口となる。

(3) 長期的協力のための対話

長期的協力のための行動に関して対話を始めるが、将来の交渉などの予断をもたない。最大 4 回のワーク ショップを開催し、COP12/13 に結果を報告する。この合意は、今後の長期的な取組みに関する対話にアメ リカや途上国を巻き込む形となった。しかし、「対話」は「交渉」ではなく、その実効性には疑問ももたれて いる。

京都議定書の今後にかなり疑問が投げかけられる中でこの会議が成果を残した背景には、CDM (クリーン 開発メカニズム）を初めとする京都メカニズムを通じて、先進国・途上国双方に関連ビジネスが生まれ、多 くの投資が行われ、市場を創り上げているということがあった。この意味で、今後市場メカニズムがいっそ う重要になることが明確になった会議ではあったが、市場主義への過剩な傾斜には要注意という見方もある。

\footnotetext{
$1 \mathrm{EU}$ の問題につき、渡邊理絵・田村堅太郎「地球温暖化対策をめぐる EUと米国の動向」資源環境対策 41 巻 1 号、2005 年、 （渡邊担当）参照。

21990 年以降、北海で産出される石油や天然ガスの優位性が高まり、従前の石炭からこれらの燃料に重点が移行している。

3 アメリカの問題につき渡邊理絵・田村堅太郎「地球温暖化対策をめぐる EUと米国の動向」資源環境対策 41 巻 1 号、2005

年 (田村担当) 参照。

4 Pew Center on Global Climate Change のホームページによる。

5 明日香壽川「途上国と地球温暖化問題」資源環境対策 41 巻 1 号 2005 年参照。

6 大塚直『環境法』65 頁以下。

7 大塚直「国内制度に関する法的手法の分析と提案」環境法政策学会編『温暖化対策へのアプローチ』2002 年。

8 足立治郎「環境税とは何汃世界 2004 年 10 月号。

9 平田仁子「求められる地球温暖化対策の強化と市民参加」資源環境対策 41 巻 1 号 2005 年。

10 インタビュー「COP11/COPMOP1 で何が決まったのか一水野理・環境省地球環境局地球温暖化対策課国際対策室長に聞

く」資源環境対策 42 巻 2 号 2006 年 2 月。

11 平田仁子“「モントリオール会議成功の意味」資源環境対策 42 巻 2 号 2006 年 2 月。
} 